\title{
The Influence Paths of Agricultural Mechanization on Green Agricultural Development
}

\author{
Yuanying Chi ${ }^{1}$, Wenbing Zhou ${ }^{1, *}$, Zhenyu Wang ${ }^{1}$, Yu Hu ${ }^{1}$ and Xiao Han ${ }^{2, *}$ \\ 1 School of Economics and Management, Beijing University of Technology, Beijing 100124, China; \\ goodcyy@bjut.edu.cn (Y.C.); wzy2019@bjut.edu.cn (Z.W.); huyucn@126.com (Y.H.) \\ 2 State Grid Information \& Telecommunication Branch, Beijing 100053, China \\ * Correspondence: zhouwb0902@163.com (W.Z.); han_tina@163.com (X.H.)
}

check for updates

Citation: Chi, Y.; Zhou, W.; Wang, Z.; $\mathrm{Hu}, \mathrm{Y}$; Han, X. The Influence Paths of Agricultural Mechanization on Green Agricultural Development. Sustainability 2021, 13, 12984. https://doi.org/10.3390/ su132312984

Academic Editor: Marco Manzone

Received: 27 October 2021

Accepted: 17 November 2021

Published: 24 November 2021

Publisher's Note: MDPI stays neutral with regard to jurisdictional claims in published maps and institutional affiliations.

Copyright: (C) 2021 by the authors Licensee MDPI, Basel, Switzerland This article is an open access article distributed under the terms and conditions of the Creative Commons Attribution (CC BY) license (https:// creativecommons.org/licenses/by/ $4.0 /)$.

\begin{abstract}
For sustainable agricultural development, increasing efforts are put on promoting agricultural mechanization and green agricultural development all over the world. Based on the panel data of Chinese provincial agriculture from 2002 to 2018, the System Generalized Method of Moments model and mediation model are constructed to explore the paths of agricultural mechanization affecting green agricultural development. The results show that agricultural mechanization can not only promote the green agricultural development directly but also indirectly by transferring the agricultural labor force and increasing fertilizer input. However, because of the surge of pesticide demand, agricultural mechanization also leads to serious pollution indirectly. With the development of large-scale agricultural machinery, the direct promotion of agricultural machinery on green agricultural development will be more significant. However, it will be less efficient to substitute more agricultural labor force with machinery power. The problem of pesticide abuse will also become more serious. Therefore, it is important for green agricultural development to encourage human capital investment in agricultural mechanization. In addition, more attention should be paid to improving the input efficiency of fertilizers and pesticides so that agriculture will be sustainable in production and the ecological environment.
\end{abstract}

Keywords: agricultural mechanization; large-scale agricultural machinery; green agricultural development; path analysis

\section{Introduction}

Promoting green agricultural development is the inevitable requirement of agricultural mechanization transformation and upgrading. The United States, which has a high level of agricultural mechanization, was the first to put forward the agricultural green subsidy program. The plan made agricultural production subsidies converted into agricultural pollution subsidies. Then Britain, Japan and other developed countries also put forward the concept of green agriculture. More advanced and green technologies are suggested to achieve sustainable agricultural development. Because of the farm machinery purchase subsidy policy, agricultural machinery's total power had increased from 579 million $\mathrm{kW}$ to 1004 million $\mathrm{kW}$ in China from 2002 to 2018. However, the rapid growth of agricultural mechanization has led to some problems, such as excess capacity in agricultural machinery, labor shortage and environmental pollution. In January 2017, the concept of "green development of agriculture" was emphasized to change the extensive development model in the 13th Five-Year Plan for the Development of National Agricultural Mechanization. Moreover, agricultural machinery was required to be "green" and tap the potential of sustainable agricultural development. Achieving green agricultural development will not only help to break constraints of resources and the environment but also improve agricultural productivity and ensure food security. Therefore, it is important for highquality development of agricultural modernization to balance the relationship between agricultural mechanization and green agricultural development. 
With the increase in agricultural machines, there are many good changes in rural agriculture development. More and more agricultural labors are moving into cities [1]. Agricultural resources and energy are used more efficiently [2]. The agricultural structure has been optimized and upgraded. These "good" changes hold the early views of scholars such as Singh (2006) that agricultural mechanization has a significant promoting effect on agricultural productivity [3]. As a result, many scholars suggested that the government should provide more subsidies to farmers who want to buy agricultural machines [4]. Meanwhile, irrational agricultural mechanization led to the rapid growth of agricultural carbon emissions, low scale efficiency of agricultural production and so on [5]. For example, Chen et al. (2021) and Aguilera et al. (2019) have proved that inefficient carbon emissions result in too much investment in agricultural machinery and hinder green agricultural development [6,7]. Increasing scholars have focused on the relationship between agricultural mechanization and green agricultural development. Sharma et al. (2021) discussed the impact of pesticide use and human capital on Greenhouse Gas emissions during agricultural mechanization [8]. Isaak et al. (2020) tried to reduce the consumption of fossil energy in sweet corn cultivation by studying the optimal scale of agricultural mechanization and the combination of production factors in Malaysia [9]. In a word, it is necessary for green agricultural development to make agricultural mechanization achieve a "qualitative" improvement rather than a quantitative increase.

There has been research on the influence of agricultural mechanization on green agricultural development. As a necessary input variable, the change of agricultural machinery input will affect the green total factor productivity (GTFP) directly. For example, Chi et al. (2021), Wang et al. (2019) and Li et al. (2021) have analyzed agricultural GTFP with the increasing machinery input [10-12]. There is a dispute between agricultural mechanization and the GTFP. Lots of scholars exposed that agricultural mechanization has a negative influence on agricultural production. Jiang et al. (2020) held that agricultural mechanization could make the energy-environment performance worse because agricultural machinery has deficiencies in energy saving and emission reduction [13]. Liu et al. (2021) found that use of agricultural mechanization with the diesel oil increasing can lead to a decrease in the GTFP [14]. However, there are also some contrary points. They indicated that green mechanization can reduce agricultural carbon emissions. He et al. (2021) found that mechanized deep ploughing and scarification can promote green agricultural development in the agricultural production of mainland China [15]. Lin and $\mathrm{Xu}$ (2018) held that the impact of agricultural mechanization on carbon emissions is heterogeneous [16]. It will be helpful to promote the application of energy-saving and emission mitigation technologies for reducing carbon emissions. Moreover, Gorjian et al. (2021) suggested deploying the modern solar-powered electric farm machinery [17]. Apriyana et al. (2021) proposed taking agricultural machinery into the Integrated Cropping calendar Information System [18]. With the popularization of these advanced agricultural machinery technologies, the development of agricultural mechanization is bound to play a more positive role in promoting the green agricultural development.

The existing literature provides a rich theoretical basis and experience reference for our research. However, there are still the following two points that should be further studied. First, most of the above literature focuses on the direct impact of agricultural mechanization on green agricultural development rather than the indirect effect of agricultural mechanization. The green agricultural development can be assessed by agricultural labor force, pesticide, fertilizer and other factors that also will change with the increase in agricultural machinery input. If we ignore the structural changes brought by agricultural mechanization, we cannot understand the mechanism of agricultural mechanization on green agricultural development. Second, because the static panel model was used in most relevant studies, the inertia and endogeneity of green agricultural development have not been investigated. The concept of green agricultural development has a strong lasting influence on agricultural green production behavior. It will force agricultural mechanization to accelerate transforming and upgrading to all-round, high-quality and efficient. Therefore, 
the results of existing studies may be biased. The green agricultural development needs more in-depth study on the impact of agricultural mechanization.

In this paper, the Generalized Method of Moments (GMM) model was constructed to deal with the inertia and endogeneity of related variables in the process of green agricultural development. Thus, the regression results are more credible. Moreover, the mediation model was used to study both the direct and indirect effects of agricultural mechanization on agricultural green development. The mechanism of agricultural mechanization affecting green agricultural development was analyzed to make up for the lack of existing literature. Therefore, the research perspective is more comprehensive. Furthermore, this paper investigated the adjustment effect of agricultural machinery upsizing on each path. Our conclusions have important reference value for the coordination of agricultural mechanization and green agricultural development under the trend of large-scale agricultural machinery.

Other parts are organized as follows. First, based on theoretical analysis, we discuss the direct and indirect mechanism of agricultural mechanization on green agricultural development. Four hypotheses are also put forward. Second, we present all the variables and methods. The mediation model and the moderated mediation model are constructed based on the stepwise regression, respectively. Third, we summarize the mediation model to expose paths of mechanization affecting green agricultural development. Fourth, the moderated mediation model is regressed to discuss the moderation of large-scale development of agricultural machinery. The final section summarizes all conclusions and puts forward some suggestions on relevant policies.

\section{Theoretical Analysis}

\subsection{The Direct Effect of Agricultural Mechanization on Green Agricultural Development}

Agricultural mechanization is the most direct reason to improve agricultural production efficiency. With the rapid rise of wages in the non-agricultural sectors, agricultural labor has flooded into the cities, which resulted in a structural shortage of agricultural labors [19]. Agricultural machines that have lower prices compared with labors can lower the cost of agricultural production and increase grain output significantly [20]. Due to the improvement of the agricultural machinery service market, agricultural mechanization will reduce the investment risk of agricultural production [21]. Cross-regional service of agricultural machinery makes agricultural mechanization not only beneficial to the local agricultural output but also to other regions' agricultural output. However, the input of agricultural machines also increases the demand for fossil fuels and aggravates agricultural pollution [22]. Therefore, it is important for protecting the agricultural ecological environment to make agricultural mechanization reasonable. When the increase in agricultural productivity is greater than that in agricultural pollution emissions, agricultural mechanization will play a significant positive role in promoting green agricultural development. On the contrary, agricultural mechanization has a negative inhibition effect.

In 2020, the mechanization rate of crop cultivation and harvest reached $71 \%$ in China. China has been making a lot of efforts in agricultural mechanization to promote green agricultural development. Firstly, backward agricultural machines are replaced with larger and more efficient agricultural machines. The positive effect of elements input on agricultural production can be improved by upgrading agricultural machinery [23] Secondly, it is important to suggest cleaner and environment-friendly agricultural machines that are characterized by higher energy efficiency and operational efficiency. The constraint of carbon emission should be strengthened to reduce the damage of agricultural machinery to the ecological environment [24]. It has been proved that agricultural mechanization plays a major role in promoting agricultural green production in China [24]. Therefore, Hypothesis 1 is proposed that

Hypothesis 1 (H1). Agricultural mechanization mainly plays a direct role in promoting the green development of agriculture in China. 


\subsection{The Indirect Effect Mechanism of Agricultural Mechanization}

According to the theory of agricultural production, the increase of agricultural machinery input will lead to the change of other elements input under the given output.

In the long-term, agricultural mechanization is bound to replace most of the agricultural labors. From the point of view of supply and demand theory, price change is the main reason for the substitution effects of agricultural machines [25]. On the one hand, technical progress reduces the price of agricultural machinery and increases the demand for agricultural machinery [2]. On the other hand, wages in non-agricultural sectors rose rapidly and accelerated the transfer of agricultural labor to non-agricultural sectors [26]. Therefore, agricultural mechanization can raise agricultural income by shifting relatively expensive labors. However, the law of decreasing marginal technology substitution rate shows that, with agricultural machines increasing, the substitution effect of agricultural machinery on agricultural labors is gradually weakened [27,28]. In particular, the emergence of new agricultural management entities has greatly improved the efficiency of labor output and the level of green agricultural development [29]. It indicates that in the long run, the substitution effect of agricultural mechanization may fail.

The development of modern agriculture has a greater dependence on chemical fertilizers and pesticides since a large amount of agricultural machines input. It is beneficial for crops to use pesticides to resist natural risks and reduce the loss of agricultural output [30]. Chemical fertilizer is also essential to increasing total agricultural yields because it greatly increases soil fertility [31]. Compared with other inputs, the price of chemical fertilizers and pesticides is lower so that there is has a greater demand for them in agricultural production [32]. Based on the law of diminishing marginal element input, excessive use of chemical fertilizers and pesticides may lead to lower input efficiency of chemical fertilizers and pesticides [33]. It also causes agricultural ecological problems such as pesticide residues, soil hardening and soil acidification [34]. Therefore, the impact of pesticide and chemical fertilizer input on green agricultural development needs to be viewed dialectically, which is similar to the input of agricultural machinery.

At present, there are a few new farmers in China, and the main trend is still that agricultural labors turn into the city. An important goal of agricultural modernization development is to make agricultural machines play an active role by accelerating the transfer of the agricultural labor force. At the same time, under the constraint of the ecological environment, more and more scholars have called for accelerating the adjustment of the agricultural input structure and reducing the input of chemical fertilizers and pesticides [35]. It has become an important challenge for green agricultural development to promote a reduction in chemical fertilizers and pesticides and increase their efficiency in China. In conclusion, we put forward the following theoretical hypotheses:

Hypothesis 2 (H2). The transfer of agricultural labors plays a significant positive mediating role between agricultural mechanization and green agricultural development.

Hypothesis 3 (H3). Pesticide investment plays a significant mediating role between agricultural mechanization and green agricultural development.

Hypothesis 4 (H4). Fertilizer input plays a significant intermediary role between agricultural mechanization and green agricultural development.

\section{Data and Methodology}

This paper selected balanced panel data of 31 provinces in China from 2002 to 2018. Hong Kong, Macao and Taiwan were excluded for lack of relevant data. All data come from the National Bureau of Statistics. Specific variable selection and models are as follows. 


\subsection{The Variable Definition}

(1) Dependent variable: cumulative index of green total factor productivity (GTFP, \%).

Based on the SBM (Slack Based Model) model that considers undesired output, we used R language to calculate the Malmquist index [36]. The SBM-Malmquist model was constructed with "variable" and "non-oriented returns to scale" hypotheses. The expected output is the gross product of agriculture, forestry, animal husbandry and fishery (100 million yuan). For eliminating the influence of price factors, the agricultural production price index is used to convert the total agricultural output value of each year based on the constant price in 2002. Undesired output is agricultural carbon emissions. Input variables include agricultural labors (ten thousand), total power of agricultural machinery (ten thousand kilowatts), the consumption of chemical fertilizers converted into a net amount (ten thousand tons), effective irrigation area (one thousand hectares), total sown area of crops (one thousand hectares), pesticide usage amount (ten thousand tons) and usage amount of agricultural plastic film (ten thousand tons). The GTFP is

$$
\operatorname{GTFP}_{t}=\left(\prod_{i=1}^{t} \text { Malmquist }_{i}\right) \times 100
$$

(2) Core dependent variable: agricultural mechanization.

The total power of agricultural machinery (ten thousand kilowatts) was used to represent the level of agricultural mechanization. The influence of agricultural machinery on agriculture is analyzed from the total amount.

(3) Mediation variables: agricultural labor transfer index ( $L T, \%)$, pesticide input per unit $(P I, \mathrm{~kg} / \mathrm{ha})$, chemical fertilizer input per unit $(F I, \mathrm{~kg} / \mathrm{ha})$ and infrastructure input (DI, \%).

$$
\begin{gathered}
L T=(1-\text { Agr_labor } / \text { All_labor }) \times 100 \\
P I=\text { Pes } / \text { All_area } \\
F I=F e r / A l l \_a r e a
\end{gathered}
$$

Here Agr_labor (ten thousand) is the number of employed persons in the rural agriculture, forestry, animal production and hunting and fishing. All_labor (ten thousand) is the number of rural employed persons. Pes is the input of pesticide usage amount $(\mathrm{kg})$. AII_area is the total sown area of crops (hectares). Fer is the consumption of chemical fertilizers converted into a net amount $(\mathrm{kg})$.

(4) Moderator Variable is the proportion of large-scale agricultural machinery $(M L, \%)$, which shows development of large-scale agricultural machinery.

$$
M L=\text { Large_power } / \text { Total_power } \times 100
$$

Here, Large_power is the total power of large and medium-sized tractors (ten thousand $\mathrm{kW}$ ). Total_power is the total power of agricultural machinery (ten thousand $\mathrm{kw}$ ).

(5) Substitution variable is agricultural machinery input per unit $(M T 2, \mathrm{~kW} / \mathrm{ha})$, which is taken as the substitute index of the level of agricultural mechanization.

$$
M T 2=\text { Total_power } / \text { All_area }
$$

(6) Control variables include energy consumption per unit $(A D, \mathrm{~kg} / \mathrm{kw})$, water consumption per unit $(A W$, thousand cubic meters $/$ ha), rate of disaster damage $(F R, \%)$, proportion of agricultural output $(A O, \%)$, proportion of agricultural service output $(A S, \%)$, sex ratio $(S E X, \%)$, the gap between urban and rural areas $(G A P, 100 \%)$, the urbanization rate (URB, 100\%).

Table 1 shows the definitions of all variables. 
Table 1. Variable Definitions.

\begin{tabular}{|c|c|c|c|}
\hline Type & Variables & Symbols & Definitions \\
\hline Dependent variable & $\begin{array}{c}\text { The level of green agricultural } \\
\text { development }\end{array}$ & GTFP & GTFP $=\prod$ Malmquist $\times 100$ \\
\hline Core independent variable & Agricultural mechanization & MT & The total power of agricultural machinery \\
\hline \multirow[t]{3}{*}{ Mediation variables } & Agricultural labor transfer index & $L T$ & $L T=(1-$ Agr_labor $/$ All_labor $) \times 100$ \\
\hline & Fertilizer input per unit & $F I$ & $F I=$ Fer $/$ All_area \\
\hline & Pesticide input per unit & PI & $P I=$ Pes $/$ All_area \\
\hline Moderator variable & $\begin{array}{l}\text { The proportion of large-scale } \\
\text { agricultural machinery }\end{array}$ & $M L$ & $M L=L a r g e_{-}$power $/$Total_power $\times 100$ \\
\hline \multirow[t]{8}{*}{ The control variables } & Energy consumption per unit & $A D$ & $\begin{array}{l}A D=\text { Consumption of diesel fuel }(\mathrm{kg}) / \text { Total } \\
\text { power of agricultural machinery }(\mathrm{kW})\end{array}$ \\
\hline & Water consumption per unit & $A W$ & $\begin{array}{l}A W=\text { Total agricultural water consumption } \\
\left(1000 \mathrm{~m}^{3}\right) / \text { Total sown area of crops (ha) }\end{array}$ \\
\hline & Rate of disaster damage & $F R$ & $\begin{array}{c}F R=\text { Disaster damage area (ha) } / \text { Total sown area } \\
\text { of crops }(\text { ha) } \times 100\end{array}$ \\
\hline & Proportion of agricultural output & $A S$ & $\begin{array}{c}A S=\text { Gross Agricultural Output (100 Million } \\
\text { Yuan)/Gross Agricultural Product of Forestry, } \\
\text { Animal Husbandry and Fisheries (100 Million } \\
\text { Yuan) } \times 100\end{array}$ \\
\hline & $\begin{array}{c}\text { Proportion of agricultural service } \\
\text { output }\end{array}$ & FS & $\begin{array}{c}\text { FS = Gross Output Value of Agriculture, Forestry, } \\
\text { Animal Husbandry and Fishery Services } \\
(100 \text { million Yuan)/Gross Product Value of } \\
\text { Agriculture, Forestry, Animal Husbandry and } \\
\text { Fishery (100 million Yuan }) \times 100\end{array}$ \\
\hline & Sex ratio & SEX & $\begin{array}{c}S E X=\text { Rural male employees } \\
\text { (ten thousand)/Rural female employees } \\
\text { (ten thousand) } \times 100\end{array}$ \\
\hline & $\begin{array}{c}\text { The gap between urban and rural } \\
\text { areas }\end{array}$ & GAP & $\begin{array}{c}\text { GAP = Per Capita Consumption Expenditure of } \\
\text { Urban Residents (Yuan)/Per Capita } \\
\text { Consumption Expenditure of Rural Residents } \\
\text { (Yuan) }\end{array}$ \\
\hline & The urbanization rate & $U R B$ & $\begin{array}{c}\text { URB }=\text { Urban Population } \\
\text { (ten thousand) } / \text { Permanent Resident Population } \\
(\text { ten thousand) } \times 100\end{array}$ \\
\hline Substitution variable & $\begin{array}{c}\text { agricultural machinery input per } \\
\text { unit }\end{array}$ & MT2 & $\begin{array}{c}\text { MT2 = Total power of agricultural machinery } \\
(\mathrm{kW}) / \text { Total sown area of crops (ha) }\end{array}$ \\
\hline
\end{tabular}

\subsection{Data Description}

Table 2 shows the descriptive statistical results. There is a large difference between variables. The distributions of MT, PI and FI are uneven. Therefore, it is necessary to properly process the original data to improve the accuracy of the regression results.

Table 2. The descriptive statistical results.

\begin{tabular}{|c|c|c|c|c|c|c|c|c|c|}
\hline Variables & Min & Max & Mean & SE & Variables & Min & Max & Mean & $\mathrm{SE}$ \\
\hline GTFP & 65.19 & 348.87 & 115.33 & 33.75 & $A D$ & 3.63 & 148.55 & 28.69 & 24.67 \\
\hline$M T$ & 93.97 & $13,353.02$ & 2813.49 & 2725.75 & $F R$ & 0 & 93.59 & 22.79 & 15.21 \\
\hline$L T$ & 37.71 & 95.11 & 70.65 & 10.84 & $A S$ & 30.2 & 73.56 & 51.65 & 8.59 \\
\hline PI & 1.42 & 59.94 & 11.57 & 131.73 & $F S$ & 0.93 & 50.88 & 3.82 & 2.88 \\
\hline$F I$ & 128.23 & 799.59 & 351.59 & 131.73 & SEX & 102.61 & 137.85 & 116.52 & 6.36 \\
\hline$M L$ & 3.911 & 98.54 & 41.29 & 23.42 & $A W$ & 5.89 & 157.81 & 32.41 & 26.96 \\
\hline \multirow[t]{2}{*}{ MT2 } & 1.51 & 26.98 & 6.1 & 3.55 & GAP & 1.69 & 7.81 & 2.72 & 0.67 \\
\hline & & & & & $U R B$ & 13.08 & 89.61 & 48.92 & 17.04 \\
\hline
\end{tabular}

For reducing the impacts of heteroscedasticity and non-essential multicollinearity, we made GTFP, MT and MT2 logarithmic and decentralized. The paper also took the logarithm of all the control variables. Particularly, $\ln F R=\ln (1+F R)$. Due to the large time span of the sample, variables may have unit roots. Therefore, the LLC test, the ADFFisher test and the IPS test were used to perform the stationarity test. Table 3 reports that all test results obviously reject the null hypothesis and variables are stationary. The basic requirements of panel model establishment are satisfied. 
Table 3. Unit root test.

\begin{tabular}{cccccccccc}
\hline Variables & LLC & $\begin{array}{c}\text { ADF- } \\
\text { Fisher }\end{array}$ & IPS & Conclusion & Variables & LLC & $\begin{array}{c}\text { ADF- } \\
\text { Fisher }\end{array}$ & $\begin{array}{c}\text { IPS } \\
\text { Conclusion }\end{array}$ \\
\hline $\ln$ GTFP & $-1.43^{*}$ & $102.00^{* * *}$ & $-1.93^{* *}$ & Stationary & $\ln A D$ & $-2.78^{* * *}$ & $171.30^{* * *}$ & $-3.26^{* * *}$ & Stationary \\
$\ln M T$ & $-5.23^{* * *}$ & $165.61^{* * *}$ & $-1.84^{* *}$ & Stationary & $\ln F R$ & $-6.23^{* * *}$ & $89.98^{* * *}$ & $-9.62^{* * *}$ & Stationary \\
$\ln L T$ & $-1.40^{*}$ & $190.27^{* * *}$ & $-3.02^{* * *}$ & Stationary & $\ln A S$ & $-4.26^{* * *}$ & $154.30^{* * *}$ & $-2.87^{* * *}$ & Stationary \\
$\ln P I$ & $-4.35^{* * *}$ & $174.64^{* * *}$ & $-1.62^{*}$ & Stationary & $\ln F S$ & $-4.78^{* * *}$ & $253.66^{* * *}$ & $-2.67^{* * *}$ & Stationary \\
$\ln \mathrm{FI}$ & $-3.21^{* * *}$ & $248.37^{* * *}$ & $-6.81^{* * *}$ & Stationary & $\ln S E X$ & $-4.57^{* * *}$ & $139.09^{* * *}$ & $-3.40^{* * *}$ & Stationary \\
$\ln M L$ & $-8.94^{* * *}$ & $248.53^{* * *}$ & $-8.88^{* * *}$ & Stationary & $\ln A W$ & $-2.86^{* * *}$ & $156.93^{* * *}$ & $-1.87^{* *}$ & Stationary \\
$\ln M T 2$ & $-11.40^{* * *}$ & $226.26^{* * *}$ & $-4.64^{* * *}$ & Stationary & $\ln G A P$ & $-2.72^{* * *}$ & $95.37^{* * *}$ & $-3.34^{* * *}$ & Stationary \\
& & & & & $\ln U R B$ & $-7.98^{* * *}$ & $150.20^{* * *}$ & $-1.98^{* *}$ & Stationary \\
\hline
\end{tabular}

Noted: ${ }^{* * *}, * *$ and $*$ reflect the $1 \%, 5 \%$ and $10 \%$ significance levels respectively.

\subsection{Methods}

(1) The base model.

The system GMM model that can avoid endogeneity is used to test the impact of agricultural mechanization on green agricultural development [37]. The lagged item of the independent variable is taken as the instrumental variable. The base model is constructed as follows:

$$
\ln \operatorname{GTFP}_{i t}=c_{0}+c_{1} \ln M T_{i t}+\sum_{1}^{j} c_{2 j} \ln \operatorname{GTFP}_{i, t-j}+\sum_{k=1}^{8} \beta_{1 k} \operatorname{Contr}_{k i t}+\mu_{1 i t}
$$

Here, $c_{0}$ is the intercept term. $c_{1}, c_{2}$ and $\beta$ are coefficients that should be estimated. $\ln \operatorname{GTFP}_{i, t-j}$ shows the $\ln \mathrm{GTFP}_{i t}$ with a lag of $j$ period. $k=1, \ldots, 8$. Contr represents 8 control variables. $i=1, \ldots, 31$, which reports provinces. The years are denoted by $t$, $t=2003, \ldots, 2018$. The $\mu$ is stochastic disturbance team.

(2) The mediation models.

The mediation model has been used to evaluate the influence paths of factors. It has been developed well in many research areas. Zhang et al. (2020) built five regression equations to investigate the impact of farm size, labors and capital input in agricultural labor productivity [38]. Chen et al. (2020) used a parallel multiple mediator model to explore the mediating effect of technology in carbon emission [39]. The mediation model that tests the mediation effect is as follows:

$$
\begin{array}{r}
M E D_{i t}=a_{0}+a_{1} \ln M T_{i t}+\sum_{1}^{j^{\prime}} a_{2 j^{\prime}} M E D_{i, t-j^{\prime}}+\sum_{k=1}^{8} \beta_{2 k} \text { Contr }_{k i t}+\mu_{2 i t} \\
\ln \operatorname{GTFP}_{i t}=c_{0}^{\prime}+c_{1}^{\prime} \ln M T_{i t}+b M E D_{i t}+\sum_{1}^{j^{\prime \prime}} c_{2 j^{\prime \prime}}^{\prime} \ln G T F P_{i, t-j^{\prime \prime}}+\sum_{k=1}^{8} \beta_{3 k} \text { Contr }_{k i t}+\mu_{3 i t}
\end{array}
$$

Here $a_{0}$ and $c_{0}^{\prime}$ are intercept terms. $a_{h}, c_{h}^{\prime}, b$ and $\beta$ are coefficients that should be estimated. $M E D$ reports mediator variables that include $\ln L T, \ln P I, \ln F I . M E D_{i, t-j^{\prime}}$ is the value of $M E D_{i t}$ with a lag of $j^{\prime}$ years. If $c_{1}^{\prime}$ is significant, Hypothesis 1 will be confirmed and increasing machinery power can promote the green agricultural development. When $M E D$ is $\ln L T$, if $a_{1}$ and $b$ are significantly positive, Hypothesis 2 is credible and the positive mediating effect of labor transfer is significant. When $M E D$ is $\ln P I$ or $\ln F I$, if $a_{1}$ and $b$ are significant, Hypotheses 3 or 4 are also reasonable.

(3) The moderated mediation models.

The moderated mediation model can accurately describe the function of how the largescale trend of agricultural machinery affects each influence path of agricultural mechanisms to green agricultural production [40]. The moderated mediation model was constructed as follows:

$$
M E D_{i t}=a_{0}+a_{1} \ln M T_{i t}+a_{2} \ln M L_{i t}+a_{3} \ln M T_{i t} \times \ln M L_{i t}+\sum_{1}^{j^{\prime}} a_{4 j^{\prime}} M E D_{i, t-j^{\prime}}+\sum_{k=1}^{8} \beta_{2 k} \operatorname{Contr}_{k i t}+\mu_{4 i t}
$$




$$
\begin{aligned}
\ln G T F P_{i t}=c_{0}^{\prime}+c_{1}^{\prime} \ln M T_{i t}+c_{2}^{\prime} \ln M L_{i t} & +c_{3}^{\prime} \ln M T_{i t} \times \ln M L_{i t}+b M E D_{i t}+\sum_{1}^{j^{\prime \prime}} c_{4 j^{\prime \prime}}^{\prime} \ln G T F P_{i, t-j^{\prime \prime}} \\
& +\sum_{k=1}^{3} \beta_{1 k} \operatorname{Contr}_{k i t}+\mu_{5 i t}
\end{aligned}
$$

If $c_{3}^{\prime}$ is significant, the trend of large-scale agricultural machinery has a direct moderating effect on the influencing path. If $a_{3}$ and $b$ are significant, the moderating effect of the large-scale trend is indirect. The relationship between variables is shown in Figure 1.

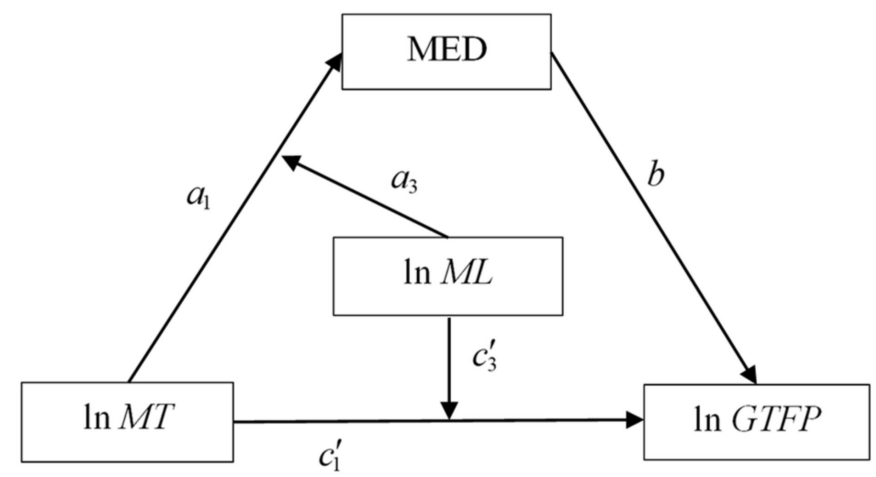

Figure 1. The moderation mechanism of the agricultural machinery large-scale trend.

\section{Results and Discussion}

\subsection{Analysis of Mediation Mechanism}

\subsubsection{Estimation Results of the Mediation Models}

Table 4 reports the results of each model. Arellano-Bond test for first-order (AR1) and second-order (AR2) serial correlation can be used to verify the autocorrelation of the disturbance term. The validity of the instrumental variables can be proved by the Sargan test. All AR (1) results reject the null hypothesis of no autocorrelation at the $10 \%$ level, but the AR (2) results do not. The results of the Sargan tests show that all instrumental variables are valid. Therefore, the setting of each model is reasonable.

The result of the base model shows that $\ln M T^{\prime}$ s coefficient is significantly 0.0731 at the $1 \%$ level. It indicates that there is a significant positive relationship between agricultural mechanization and green agricultural development in China. All coefficients of $\ln M T$ in column 2 in each path are also significantly positive at the level of 5\%. The rationality of the agricultural mechanization in China is verified again. Hypothesis 1 is proven. With the transformation and upgrading of agricultural mechanization, increasing investment in agricultural machines will lead to a more direct promoting effect on the green development of agriculture. It is important for China to persist in promoting agricultural mechanization and increase the total input of agricultural machinery in agricultural production.

Table 4 also shows that the transfer of agricultural labor force and the input of chemical fertilizer play partial positive mediating roles between agricultural mechanization and green agricultural development, while the input of pesticide plays a partial negative mediating role.

(1) Agricultural mechanization indirectly raises the GTFP by transferring agricultural labors. In Path 1, the coefficients of $\ln M T$ in column 1 and $\ln L T$ in column 2 are positive at the $1 \%$ level significantly. Because of agricultural mechanization, agricultural labors that are more expensive than machines are gradually being replaced so that the cost of agricultural input is reduced. The coefficient of $\ln L T_{t-1}$ in column 1, which is significantly positive at the $1 \%$ level, proves that agricultural labors have the inertia of spontaneous transfer to non-agricultural sectors in China. As sectoral wage differentials widen, there will be more and more labor vacancies in the agricultural sector [41]. It indicates that agricultural mechanization still has greater development potential in China. 
Table 4. Estimation results of the mediation models.

\begin{tabular}{|c|c|c|c|c|c|c|c|}
\hline & \multirow{2}{*}{$\begin{array}{c}\text { Base Model } \\
\ln G T F P\end{array}$} & \multicolumn{2}{|c|}{ Path 1} & \multicolumn{2}{|c|}{ Path 2} & \multicolumn{2}{|c|}{ Path 3} \\
\hline & & $\ln L T$ & $\ln G T F P$ & $\ln P I$ & $\ln G T F P$ & $\ln F I$ & $\ln G T F P$ \\
\hline $\ln M T$ & $\begin{array}{c}0.0731^{* * *} \\
(4.33)\end{array}$ & $\begin{array}{c}0.0368^{* * * *} \\
(4.20)\end{array}$ & $\begin{array}{c}0.0627^{* * * *} \\
(4.25)\end{array}$ & $\begin{array}{c}0.0702^{* * *} \\
(3.12)\end{array}$ & $\begin{array}{c}0.0725^{* * *} \\
(3.53)\end{array}$ & $\begin{array}{c}0.0710^{* * *} \\
(4.42)\end{array}$ & $\begin{array}{c}0.0360 \text { ** } \\
(2.05)\end{array}$ \\
\hline $\ln L T$ & & & $\begin{array}{c}0.2887^{* * *} \\
(5.75)\end{array}$ & & & & \\
\hline $\ln P I$ & & & & & $\begin{array}{c}-0.0500 * * * \\
(-3.63)\end{array}$ & & \\
\hline $\ln F I$ & & & & & & & $\begin{array}{c}0.1435^{* * *} \\
(7.34)\end{array}$ \\
\hline $\ln G T F P_{t-1}$ & $\begin{array}{c}0.8292^{* * *} \\
(25.01)\end{array}$ & & $\begin{array}{c}0.8117^{* * * *} \\
(22.88)\end{array}$ & & $\begin{array}{c}0.8600^{* * *} \\
(31.16)\end{array}$ & & $\begin{array}{c}0.8082^{* * *} \\
(43.79)\end{array}$ \\
\hline $\ln L T_{t-1}$ & & $\begin{array}{c}0.4317^{* * *} \\
(18.16)\end{array}$ & & & & & \\
\hline $\ln P I_{t-1}$ & & & & $\begin{array}{c}0.7878^{* * *} \\
(19.08)\end{array}$ & & & \\
\hline $\ln P I_{t-2}$ & & & & $\begin{array}{c}0.0991^{* * * *} \\
(2.71)\end{array}$ & & & \\
\hline $\ln F I_{t-1}$ & & & & & & $\begin{array}{c}0.7788^{* * *} \\
(27.22)\end{array}$ & \\
\hline Controls & Yes & Yes & Yes & Yes & Yes & Yes & Yes \\
\hline Wald chi ${ }^{2}$ & 14,175 & 6615 & 18,692 & 9308 & 53,405 & $21,473.64$ & 33,053 \\
\hline Sargan test & 0.8352 & 0.6554 & 0.7677 & 0.9563 & 0.9105 & 0.6744 & 0.8715 \\
\hline $\mathrm{AR}(1)$ & 0.0714 & 0.0571 & 0.0756 & 0.0003 & 0.0703 & 0.0013 & 0.0745 \\
\hline $\mathrm{AR}(2)$ & 0.9198 & 0.6396 & 0.8853 & 0.1928 & 0.9354 & 0.1283 & 0.8285 \\
\hline $\mathrm{N}$ & 496 & 496 & 496 & 465 & 496 & 496 & 496 \\
\hline
\end{tabular}

Noted: ${ }^{* * *}, * *$ and ${ }^{*}$ reflect the $1 \%, 5 \%$ and $10 \%$ significance levels respectively.

(2) Agricultural mechanization has led to a huge increase in the demand for pesticides and fertilizers. However, the impact of chemical fertilizer input on green agricultural development is significantly negative. In most parts of China, pesticide abuse may be a problem. Pesticide input has less incentive to agricultural production than pollution to the agricultural environment. The chemical fertilizer input is more reasonable so it is more helpful to agricultural production than to environmental pollution. Coefficients of $\ln F I_{t-1}$ and $\ln P I_{t-1}$ are significantly positive at the $1 \%$ level. It is obvious that the investment in pesticide and chemical fertilizer also has a long-term growth trend. It indicates that there will be more and more pesticides and fertilizers in agriculture. Therefore, it is necessary to improve the development of agricultural mechanization and change the extensive agricultural mode.

\subsubsection{Robust Tests}

Two kinds of Robustness tests are used to verify the rationality of the models. Firstly, the differential GMM model is utilized as a stability test, and the regression results are shown in Table 5. Secondly, we substitute $\ln M T 2$ for $\ln M T$ and use the GMM model to analyze the influence path of agricultural mechanization. Table 6 reports those regression results. The regression results in Tables 5 and 6 and Table 4 are highly consistent in terms of positivity and significance. It shows that labor transfer, pesticide input and chemical fertilizer input all have stable mediating effects between agricultural mechanization and green agricultural development. Therefore, Hypotheses 2, 3 and 4 are proved. 
Table 5. Robust test 1: the differential GMM model.

\begin{tabular}{|c|c|c|c|c|c|c|c|}
\hline & \multirow{2}{*}{$\begin{array}{c}\text { Base Model } \\
\ln G T F P\end{array}$} & \multicolumn{2}{|c|}{ Path 1} & \multicolumn{2}{|c|}{ Path 2} & \multicolumn{2}{|c|}{ Path 3} \\
\hline & & $\ln L T$ & $\ln G T F P$ & $\ln P I$ & $\ln$ GTFP & $\ln F I$ & $\ln G T F P$ \\
\hline $\ln M T$ & $\begin{array}{c}0.1193^{* * * *} \\
(3.21)\end{array}$ & $\begin{array}{c}0.0250 \text { ** } \\
(4.02)\end{array}$ & $\begin{array}{c}0.1002^{* * *} \\
(2.68)\end{array}$ & $\begin{array}{c}0.0542 * * * \\
(2.77)\end{array}$ & $\begin{array}{c}0.1047 \text { ** } \\
(2.33)\end{array}$ & $\begin{array}{c}0.0470 * * * \\
(3.05)\end{array}$ & $\begin{array}{c}0.0853 \text { ** } \\
(2.55)\end{array}$ \\
\hline $\ln L T$ & & & $\begin{array}{c}0.2479^{* * *} \\
(3.43)\end{array}$ & & & & \\
\hline $\ln P I$ & & & & & $\begin{array}{c}-0.0557^{* * *} \\
(-2.94)\end{array}$ & & \\
\hline $\ln F I$ & & & & & & & $\begin{array}{c}0.1519^{* * *} \\
(8.05)\end{array}$ \\
\hline $\ln G T F P_{t-1}$ & $\begin{array}{c}0.6072^{* * *} \\
(22.53)\end{array}$ & & $\begin{array}{c}0.762 * * * \\
(18.68)\end{array}$ & & $\begin{array}{c}0.6641^{* * *} \\
(19.75)\end{array}$ & & $\begin{array}{c}0.5824^{* * *} \\
(23.68)\end{array}$ \\
\hline $\ln L T_{t-1}$ & & $\begin{array}{c}0.3225^{* * *} \\
(21.71)\end{array}$ & & & & & \\
\hline $\ln P I_{t-1}$ & & & & $\begin{array}{c}0.7791^{* * *} \\
(28.79)\end{array}$ & & & \\
\hline $\ln P I_{t-2}$ & & & & $\begin{array}{c}0.1702 * * * \\
(5.32)\end{array}$ & & & \\
\hline $\ln F I_{t-1}$ & & & & & & $\begin{array}{c}0.6663 * * * \\
(15.19)\end{array}$ & \\
\hline Controls & Yes & Yes & Yes & Yes & Yes & Yes & Yes \\
\hline Wald chi ${ }^{2}$ & $28,786.99$ & 8684.05 & $16,822.02$ & $18,821.68$ & $44,958.54$ & 4936.88 & $26,232.92$ \\
\hline Sargan test & 0.1778 & 0.5594 & 0.1077 & 0.7329 & 0.3233 & 0.0932 & 0.2055 \\
\hline AR (1) & 0.0921 & 0.2013 & 0.0932 & 0.0009 & 0.0862 & 0.0011 & 0.0994 \\
\hline AR (2) & 0.8297 & 0.2821 & 0.7989 & 0.6724 & 0.8536 & 0.0736 & 0.7404 \\
\hline $\mathrm{N}$ & 496 & 496 & 496 & 465 & 496 & 496 & 496 \\
\hline
\end{tabular}

Noted: ${ }^{* * *}, * *$ and ${ }^{*}$ reflect the $1 \%, 5 \%$ and $10 \%$ significance levels respectively.

Table 6. Robust test 2: Replace $\ln M T$.

\begin{tabular}{|c|c|c|c|c|c|c|c|}
\hline & \multirow{2}{*}{$\begin{array}{c}\text { Base Model } \\
\ln G T F P\end{array}$} & \multicolumn{2}{|c|}{ Path 1} & \multicolumn{2}{|c|}{ Path 2} & \multicolumn{2}{|c|}{ Path 3} \\
\hline & & $\ln L T$ & $\ln G T F P$ & $\ln P I$ & $\ln$ GTFP & $\ln F I$ & $\ln G T F P$ \\
\hline $\ln M T 2$ & $\begin{array}{c}0.0846^{* * *} \\
(5.89)\end{array}$ & $\begin{array}{c}0.0263^{* * *} \\
(2.70)\end{array}$ & $\begin{array}{c}0.0778^{* * * *} \\
(5.40)\end{array}$ & $\begin{array}{c}0.19911^{* * *} \\
(5.75)\end{array}$ & $\begin{array}{c}0.0987^{* * * *} \\
(5.21)\end{array}$ & $\begin{array}{c}0.2649^{* * * *} \\
(10.87)\end{array}$ & $\begin{array}{l}0.0484 \text { ** } \\
(2.29)\end{array}$ \\
\hline $\ln L T$ & & & $\begin{array}{c}0.2723^{* * *} \\
(5.33)\end{array}$ & & & & \\
\hline $\ln P I$ & & & & & $\begin{array}{c}-0.0632 * * * \\
(-4.76)\end{array}$ & & \\
\hline $\ln F I$ & & & & & & & $\begin{array}{c}0.1139^{* * *} \\
(4.47)\end{array}$ \\
\hline $\ln G T F P_{t-1}$ & $\begin{array}{c}0.8113^{* * *} \\
(45.49)\end{array}$ & & $\begin{array}{c}0.8161^{* * *} \\
(24.60)\end{array}$ & & $\begin{array}{c}0.8729 * * * \\
(27.43)\end{array}$ & & $\begin{array}{c}0.8344^{* * *} \\
(34.94)\end{array}$ \\
\hline $\ln L T_{t-1}$ & & $\begin{array}{c}0.4475^{* * *} \\
(19.48)\end{array}$ & & & & & \\
\hline $\ln P I_{t-1}$ & & & & $\begin{array}{c}0.7233 * * * \\
(24.84)\end{array}$ & & & \\
\hline $\ln P I_{t-2}$ & & & & $\begin{array}{c}0.0829 * * \\
(2.92)\end{array}$ & & & \\
\hline $\ln F I_{t-1}$ & & & & & & $\begin{array}{c}0.6032^{* * *} \\
(22.48)\end{array}$ & \\
\hline Controls & Yes & Yes & Yes & Yes & Yes & Yes & Yes \\
\hline Wald chi ${ }^{2}$ & $22,578.47$ & $19,751.03$ & $14,009.68$ & 5999.29 & $26,265.24$ & 5146.35 & $142,278.27$ \\
\hline Sargan test & 0.8399 & 0.6970 & 0.7493 & 0.9948 & 0.8865 & 0.9969 & 0.9086 \\
\hline $\mathrm{AR}(1)$ & 0.0779 & 0.0550 & 0.0734 & 0.0010 & 0.0722 & 0.0014 & 0.0671 \\
\hline $\mathrm{AR}(2)$ & 0.9157 & 0.6877 & 0.8874 & 0.1895 & 0.9446 & 0.1163 & 0.8565 \\
\hline $\mathrm{N}$ & 496 & 496 & 496 & 465 & 496 & 496 & 496 \\
\hline
\end{tabular}




\subsection{Analysis of Moderation Mechanism}

According to the concept of beautiful countryside, China's agricultural machinery is showing a diversified trend that is larger, characteristic, intelligent and so on. The largescale trend of agricultural machinery is the most significant because of the subsidy policy, cross-regional service and land transfer. From 2010 to 2017, the number of large and medium-sized tractors in China raised from 3,921,700 to 6,708,000, an increase of nearly $70.86 \%$ calculated based on data from the National Bureau of Statistics. The moderation effect of the large-scale trend of agricultural machinery on each path will be studied as follows.

\subsubsection{Estimation Results of Moderated Mediation Models}

As shown in Table 7, the coefficients of $\ln M T \times \ln M L$ in the second column are all significantly positive at the $10 \%$ level. The higher the proportion of large agricultural machinery, the more agricultural mechanization can benefit the green development of agriculture directly. It indicates that the application of large agricultural machinery has promoted the supply-side structural reform of agricultural mechanization in China. The increase of the proportion of large agricultural machinery has greatly promoted the level of agricultural mechanization so that it provides strong support for green agricultural development.

Table 7. Estimation results of moderated mediation models.

\begin{tabular}{|c|c|c|c|c|c|c|}
\hline & \multicolumn{2}{|c|}{ Path 1} & \multicolumn{2}{|c|}{ Path 2} & \multicolumn{2}{|c|}{ Path 3} \\
\hline & $\ln L T$ & $\ln G T F P$ & $\ln P I$ & $\ln G T F P$ & $\ln F I$ & $\ln G T F P$ \\
\hline $\ln M T$ & $\begin{array}{c}0.0160 * \\
(1.88)\end{array}$ & $\begin{array}{c}0.0366 * \\
(1.85)\end{array}$ & $\begin{array}{c}0.0647^{* *} \\
(2.06)\end{array}$ & $\begin{array}{c}0.0656^{* * *} \\
(2.71)\end{array}$ & $\begin{array}{c}0.0676^{* * *} \\
(3.34)\end{array}$ & $\begin{array}{c}0.0361 \text { ** } \\
(2.34)\end{array}$ \\
\hline $\ln L T$ & & $\begin{array}{c}0.2385^{* * *} \\
(4.04)\end{array}$ & & & & \\
\hline $\ln P I$ & & & & $\begin{array}{c}-0.0649 * * \\
(-2.25)\end{array}$ & & \\
\hline $\ln F I$ & & & & & & $\begin{array}{c}0.1299 \text { *** } \\
(5.69)\end{array}$ \\
\hline $\ln M L$ & $\begin{array}{c}0.0236^{* * *} \\
(3.85)\end{array}$ & $\begin{array}{c}0.0346^{* *} \\
(2.17)\end{array}$ & $\begin{array}{l}-0.0272 \\
(-1.49)\end{array}$ & $\begin{array}{c}0.0349 * \\
(1.96)\end{array}$ & $\begin{array}{l}-0.0058 \\
(-0.73)\end{array}$ & $\begin{array}{c}0.0316^{* *} \\
(1.99)\end{array}$ \\
\hline $\ln M L \times \ln M T$ & $\begin{array}{c}-0.0265 \text { * } \\
(-1.67)\end{array}$ & $\begin{array}{c}0.0877^{* * *} \\
(3.26)\end{array}$ & $\begin{array}{l}0.0088 \\
(0.16)\end{array}$ & $\begin{array}{c}0.0594 \text { * } \\
(1.88)\end{array}$ & $\begin{array}{l}-0.0333 \\
(-1.08)\end{array}$ & $\begin{array}{c}0.0838^{* * *} \\
(3.21)\end{array}$ \\
\hline $\ln G T F P_{t-1}$ & & $\begin{array}{c}0.83511^{* *} \\
(17.68)\end{array}$ & & $\begin{array}{c}0.8232 * * * \\
(19.63)\end{array}$ & & $\begin{array}{c}0.7734^{* * *} \\
(32.00)\end{array}$ \\
\hline $\ln L T_{t-1}$ & $\begin{array}{c}0.4164^{* * *} \\
(17.09)\end{array}$ & & & & & \\
\hline $\ln P I_{t-1}$ & & & $\begin{array}{c}0.8111^{* * * *} \\
(14.18)\end{array}$ & & & \\
\hline $\ln P I_{t-2}$ & & & $\begin{array}{c}0.0927 * \\
(1.71)\end{array}$ & & & \\
\hline $\ln F I_{t-1}$ & & & & & $\begin{array}{c}0.7830^{* * *} \\
(23.89)\end{array}$ & \\
\hline $\begin{array}{c}\text { Control } \\
\text { variables }\end{array}$ & Yes & Yes & Yes & Yes & Yes & Yes \\
\hline Wald chi ${ }^{2}$ & $15,445.90$ & $22,668.10$ & 2387.62 & $24,007.33$ & $23,452.32$ & $13,000.23$ \\
\hline Sargan test & 0.7672 & 0.7806 & 0.9944 & 0.8673 & 0.7764 & 0.8882 \\
\hline AR (1) & 0.0645 & 0.0695 & 0.0005 & 0.0707 & 0.0010 & 0.0756 \\
\hline $\operatorname{AR}(2)$ & 0.5527 & 0.8450 & 0.2190 & 0.9036 & 0.1316 & 0.8264 \\
\hline $\mathrm{N}$ & 496 & 496 & 465 & 496 & 496 & 496 \\
\hline
\end{tabular}

Noted: ${ }^{* * *}, * *$ and $*$ reflect the $1 \%, 5 \%$ and $10 \%$ significance levels respectively.

In Path 1, the coefficient of $\ln M T \times \ln M L$ in the first column is -0.0265 significantly at the $10 \%$ level. The coefficient of $\ln L T$ is 0.2385 significantly at the $1 \%$ level. When the proportion of large agricultural machinery is high, one unit of agricultural machinery input 
will replace less agricultural labor. As a result, there will be a smaller indirect effect of agricultural machinery that is based on agricultural labor transfer. In Path 2 and Path 3, both coefficients of $\ln M T \times \ln M L$ are negative but not significant at the $10 \%$ level. In the process of large-scale development of agricultural machinery, the pollution of pesticides and fertilizers to the ecological environment may be becoming more and more serious. Another examination should be used to explore the moderation mechanism of agricultural machinery with the large-scale trend.

\subsubsection{Test of Moderation Mechanism}

The simple slope test is chosen to verify the moderation mechanism of the large-scale trend of agricultural mechanization [42]. First, the value of $\ln M L$ is plus or minus one standard deviation, respectively. Then the moderated mediation models are calculated, and the changes of each path at different values of $\ln M L$ are drawn in Figure 2. Figure 2 proves that the upsizing of agricultural machinery has significant direct and indirect moderating effects on each path.

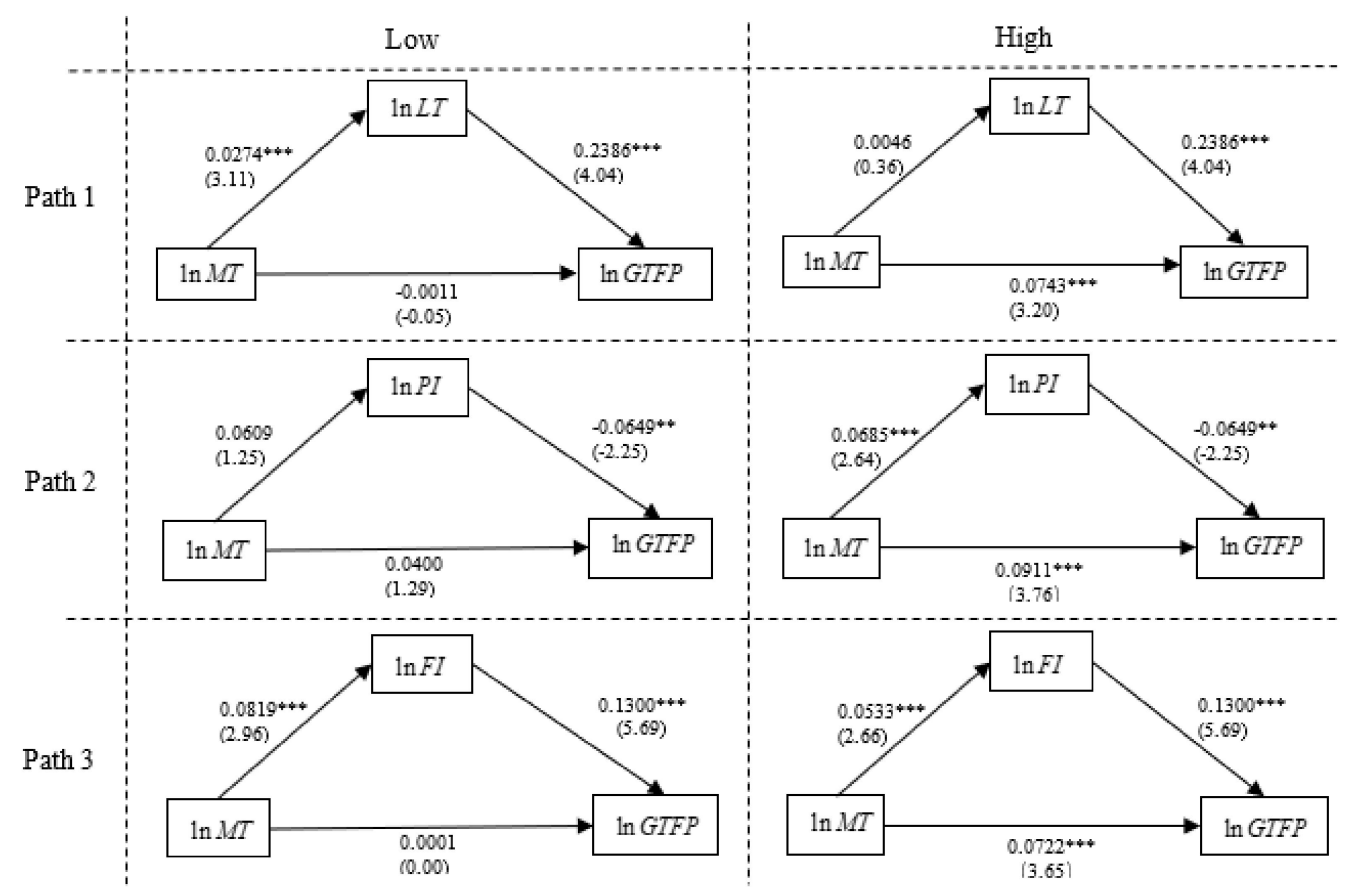

Figure 2. Test results of the moderation mechanism. Noted: ${ }^{* *},{ }^{* *}$ and ${ }^{*}$ reflect the $1 \%, 5 \%$ and $10 \%$ significance levels respectively.

In Path 1 , when $\ln M L$ is subtracted by one standard deviation, the positive mediating effect of $\ln L T$ is significant. When $\ln M L$ goes up by one standard deviation, the mediating effect of $\ln L T$ become smaller and not significant at the $10 \%$ level. It shows that the large-scale trend of agricultural machinery has a significant indirect negative regulating effect on Path 1. There were surplus agricultural labors at the early stage of agricultural mechanization. The application of agricultural machinery could transfer lots of agricultural labors with low-output efficiency effectively. However, most of those machines were small and caused serious pollution to the environment. With the development of agricultural mechanization, the problem of agricultural "hollowing out" is becoming more and more serious. The shortage of labor supply has become the main problem that restricts green agricultural development in China. At present, local governments should pay attention to the "employment creation" function of agricultural machinery upgrading. The government should increase investment in agricultural human capital to cultivate and introduce highquality agricultural personnel. 
In Path 2, when $\ln M L$ is subtracted by one standard deviation, the negative mediating effect of $\ln P I$ is not significant. When $\ln M L$ goes up by one standard deviation, the negative mediating effect of $\ln P I$ becomes more significant. At the early stage of agricultural mechanization, there were many labors and small farm machinery for weeding, deworming and so on. The higher the proportion of large agricultural machinery, the stronger the dependence of agricultural production on pesticides. Because pesticides possess the advantages of a low price and quick effect, agricultural mechanization has boosted the demand for pesticides so that agricultural production has caused great pressure on the ecological environment. For improving the efficiency of pesticide inputs, it is of importance to standardize agricultural use standards and accelerate the mechanization of pesticide spraying.

In Path 3, when the proportion of large agricultural machinery goes from low to high, the positive mediating effect of $\ln F I$ becomes weaker. It indicates that the large-scale trend of agricultural machinery has a significant indirect negative adjustment effect on Path 3 . It is important for agricultural mechanization to use lots of fertilizer. The more agricultural machinery is invested in, the more chemical fertilizer is used. With the large-scale trend of agricultural machinery, artificial fertilization will be replaced with agricultural machinery fertilization gradually. Moreover, the popularization of the green production concept has accelerated the promotion of organic fertilizers, such as livestock manure and agricultural waste. The efficiency of chemical fertilizer input will be improved. As a result, with the large-scale trend of agricultural machinery, agricultural production will be less dependent on fertilizer input.

\section{Conclusions}

For many countries, promoting agricultural mechanization is an important way to increase agricultural production and reduce agricultural pollution emissions. It is important for green agricultural development to understand how machinery input affects GTFP. In addition, the sustainable development of global agriculture will face more opportunities and challenges in the future because of the trend of large-scale development of agricultural machinery. We analyzed the influence path of agricultural mechanization on green agricultural development. The system GMM model was constructed based on the provincial panel data from 2002 to 2018 in China. Then labor transfer, fertilizer input and pesticide input were taken as intermediate variables to study the impact path of agricultural mechanization. Moreover, the changing regular of different paths was explored under different proportions of large agricultural machinery. The results show that agricultural mechanization not only promotes the green development of agriculture directly but also indirectly by transferring the agricultural labor force and increasing chemical fertilizer input. However, due to the surge of pesticide demand, agricultural mechanization also has caused more serious indirect pollution to the ecological environment. When the proportion of large-scale agricultural machinery is high, agricultural machinery input has a more obvious and direct effect in promoting the green development of agriculture. Moreover, the large-scale trend of agricultural machinery can alleviate the demand for chemical fertilizer and help reduce the dependence of green agricultural production on chemical fertilizer input. However, the large-scale trend of agricultural machinery may make the substitution effect of agricultural machinery on the agricultural labor force out of function. It also fails to promote the effective integration of agricultural machinery and pesticides. As a result, pesticide input increases so rapidly that it aggravates the deterioration of the agricultural ecological environment.

Countries all over the world are speeding up the development of agricultural mechanization. There are some new directions of agricultural technology development that include informatization, intelligence, scale and so on. For example, with the improvement of the transfer system of land contractual management rights, the large-scale trend of agricultural machinery will be further enhanced in China. Some suggestions on agricultural mechanization are put forward based on the concept of green agricultural development: 
(1) Promote agricultural human capital investment by agricultural mechanization. The agricultural mechanization with high quality not only can replace the surplus labor force but can also cultivate new labors. Therefore, the government should strengthen the investment of modern agricultural human capital. On the one hand, the government should formulate preferential policies for human capital agricultural employment. The supply structure of agricultural labors can be optimized and upgraded by training and introducing new modern agricultural talents. On the other hand, education and training system about local agricultural mechanization should be improved to realize the transformation of local "old farmers" to "new modern farmers". It will be helpful to share the fruits of agricultural modernization with local farmers.

(2) Transform and upgrade agricultural mechanization based on the green production concept. The large-scale transformation of agricultural machinery provides an opportunity to realize the reduction and efficiency improvement of chemical fertilizers and pesticides. The government should publicize the concept of green agricultural production and strengthen the training of green agricultural production actively. Those actions will be helpful for farmers to allocate the production factors input of agricultural machinery, chemical fertilizer, pesticide and so on scientifically and rationally. It is also important to promote the popularization of new green agricultural mechanization technologies that can increase the input efficiency of chemical fertilizers and pesticides. For example, deep loosening, no-tillage sowing, layered fertilizing and taking intelligent, precise application technology.

Author Contributions: Conceptualization, Y.C. and W.Z.; methodology, W.Z. and Y.H.; software, W.Z.; validation, Y.C., W.Z. and X.H.; formal analysis, Y.C., W.Z., Z.W., Y.H. and X.H.; investigation, W.Z.; resources, Y.C. and Z.W.; data curation, W.Z. and X.H.; writing-original draft preparation, Y.C. and W.Z.; writing - review and editing, W.Z. and Y.H.; visualization, Y.C. and W.Z.; supervision and translation, W.Z., Z.W., Y.H. and X.H.; funding acquisition, Y.C. All authors have read and agreed to the published version of the manuscript.

Funding: The article was supported by the Humanities and Social Science Planning Fund project of Ministry of Education of China (no. 21YJA790009) and Key project of Decision consultation of Beijing Social Science Foundation (no. 21JCB106).

Institutional Review Board Statement: Not applicable.

Informed Consent Statement: Not applicable.

Data Availability Statement: Publicly available data were analyzed in this study. The data can be found here: http:/ / www.stats.gov.cn/ (accessed on 16 November 2021).

Conflicts of Interest: The authors declare no conflict of interest.

\section{References}

1. Lu, H.; Xie, H.; Chen, Q.; Jiang, J. Impact of Agricultural Labor Transfer and Structural Adjustment on Chemical Application: Comparison of Past Developments in the Ecological Civilization Pilot Zones of China and Their Future Implications. Sustainability 2018, 10, 1909. [CrossRef]

2. Belton, B.; Win, M.T.; Zhang, X.; Filipski, M. The rapid rise of agricultural mechanization in Myanmar. Food Policy 2021, 101, 102095. [CrossRef]

3. Singh, G. Estimation of a Mechanisation Index and Its Impact on Production and Economic Factors-A Case Study in India. Biosyst. Eng. 2006, 93, 99-106. [CrossRef]

4. Zhang, R.; Ma, W.; Liu, J. Impact of government subsidy on agricultural production and pollution: A game-theoretic approach. J. Clean. Prod. 2021, 285, 124806. [CrossRef]

5. Chen, Y.; Miao, J.; Zhu, Z. Measuring green total factor productivity of China's agricultural sector: A three-stage SBM-DEA model with non-point source pollution and CO2 emissions. J. Clean. Prod. 2021, 318, 128543. [CrossRef]

6. Chen, P.; Yu, M.; Chang, C.; Hsu, S. Total factor productivity growth in China's agricultural sector. China Econ. Rev. 2008, 19, 580-593. [CrossRef]

7. Aguilera, E.; Guzmán, G.I.; de Molina, M.G.; Soto, D.; Infante-Amate, J. From animals to machines. The impact of mechanization on the carbon footprint of traction in Spanish agriculture: 1900-2014. J. Clean. Prod. 2019, 221, 295-305. [CrossRef]

8. Sharma, G.D.; Shah, M.I.; Shahzad, U.; Jain, M.; Chopra, R. Exploring the nexus between agriculture and greenhouse gas emissions in BIMSTEC region: The role of renewable energy and human capital as moderators. J. Environ. Manag. 2021, 297, 113316. [CrossRef] 
9. Isaak, M.; Yahya, A.; Razif, M.; Mat, N. Mechanization status based on machinery utilization and workers' workload in sweet corn cultivation in Malaysia. Comput. Electron. Agric. 2020, 169, 105208. [CrossRef]

10. Chi, Y.; Xu, Y.; Wang, X.; Jin, F.; Li, J. A Win-Win Scenario for Agricultural Green Development and Farmers' Agricultural Income: An Empirical Analysis Based on the EKC Hypothesis. Sustainability 2021, 13, 8278. [CrossRef]

11. Wang, Y.; Xie, L.; Zhang, Y.; Wang, C.; Yu, K. Does FDI Promote or Inhibit the High-Quality Development of Agriculture in China? An Agricultural GTFP Perspective. Sustainability 2019, 11, 4620. [CrossRef]

12. Li, J.; Chen, J.; Liu, H. Sustainable Agricultural Total Factor Productivity and Its Spatial Relationship with Urbanization in China. Sustainability 2021, 13, 6773. [CrossRef]

13. Jiang, M.; Hu, X.; Chunga, J.; Lin, Z.; Fei, R. Does the popularization of agricultural mechanization improve energy-environment performance in China's agricultural sector? J. Clean. Prod. 2020, 276, 124210. [CrossRef]

14. Liu, D.; Zhu, X.; Wang, Y. China's agricultural green total factor productivity based on carbon emission: An analysis of evolution trend and influencing factors. J. Clean. Prod. 2021, 278, 123692. [CrossRef]

15. He, P.; Zhang, J.; Li, W. The role of agricultural green production technologies in improving low-carbon efficiency in China: Necessary but not effective. J. Environ. Manag. 2021, 293, 112837. [CrossRef]

16. Lin, B.; $\mathrm{Xu}, \mathrm{B}$. Factors affecting $\mathrm{CO}_{2}$ emissions in China's agriculture sector: A quantile regression. Renew. Sustain. Energy Rev. 2018, 94, 15-27. [CrossRef]

17. Gorjian, S.; Ebadi, H.; Trommsdorff, M.; Sharon, H.; Demant, M.; Schindele, S. The advent of modern solar-powered electric agricultural machinery: A solution for sustainable farm operations. J. Clean. Prod. 2021, 292, 126030. [CrossRef]

18. Apriyana, Y.; Surmaini, E.; Estiningtyas, W.; Pramudia, A.; Ramadhani, F.; Suciantini, S.; Susanti, E.; Purnamayani, R.; Syahbuddin, H. The Integrated Cropping Calendar Information System: A Coping Mechanism to Climate Variability for Sustainable Agriculture in Indonesia. Sustainability 2021, 13, 6495. [CrossRef]

19. Osabohien, R.; Wiredu, A.; Nguezet, P.; Mignouna, D.; Abdoulaye, T.; Manyong, V.; Bamba, Z.; Awotide, B. Youth Participation in Agriculture and Poverty Reduction in Nigeria. Sustainability 2021, 13, 7795. [CrossRef]

20. Takeshima, H.; Hatzenbuehler, P.L.; Edeh, H.O. Effects of agricultural mechanization on economies of scope in crop production in Nigeria. Agric. Syst. 2020, 177, 102691. [CrossRef]

21. Banerjee, S.; Punekar, R.M. A sustainability-oriented design approach for agricultural machinery and its associated service ecosystem development. J. Clean. Prod. 2020, 264, 121642. [CrossRef]

22. Li, J.; Rodriguez, D.; Tang, X. Effects of land lease policy on changes in land use, mechanization and agricultural pollution. Land Use Policy 2017, 64, 405-413. [CrossRef]

23. Shah, S.M.; Liu, G.; Yang, Q.; Casazza, M.; Agostinho, F.; Giannetti, B.F. Sustainability assessment of agriculture production systems in Pakistan: A provincial-scale energy-based evaluation. Ecol. Model. 2021, 455, 109654. [CrossRef]

24. Lang, J.; Tian, J.; Zhou, Y.; Li, K.; Chen, D.; Huang, Q.; Xing, X.; Zhang, Y.; Cheng, S. A high temporal-spatial resolution air pollutant emission inventory for agricultural machinery in China. J. Clean. Prod. 2018, 183, 1110-1121. [CrossRef]

25. Qiao, F. Increasing wage, mechanization, and agriculture production in China. China Econ. Rev. 2017, 46, 249-260. [CrossRef]

26. Qiu, T.; Shi, X.; He, Q.; Luo, B. The paradox of developing agricultural mechanization services in China: Supporting or kicking out smallholder farmers? China Econ. Rev. 2021, 69, 101680. [CrossRef]

27. Paudel, G.P.; Gartaula, H.; Rahut, D.B.; Craufurd, P. Gender differentiated small-scale farm mechanization in Nepal hills: An application of exogenous switching treatment regression. Technol. Soc. 2020, 61, 101250. [CrossRef]

28. Paudel, G.P.; Kc, D.B.; Rahut, D.B.; Justice, S.E.; McDonald, A.J. Scale-appropriate mechanization impacts on productivity among smallholders: Evidence from rice systems in the mid-hills of Nepal. Land Use Policy 2019, 85, 104-113. [CrossRef]

29. Li, F.; Feng, S.; Lu, H.; Qu, F.; D’Haese, M. How do non-farm employment and agricultural mechanization impact on large-scale farming? A spatial panel data analysis from Jiangsu Province, China. Land Use Policy 2021, 107, 105517. [CrossRef]

30. Guo, L.; Li, H.; Cao, X.; Cao, A.; Huang, M. Effect of agricultural subsidies on the use of chemical fertilizer. J. Environ. Manag. 2021, 299, 113621. [CrossRef]

31. Muscolo, A.; Romeo, F.; Marra, F.; Mallamaci, C. Recycling agricultural, municipal and industrial pollutant wastes into fertilizers for a sustainable healthy food production. J. Environ. Manag. 2021, 300, 113771. [CrossRef] [PubMed]

32. Lu, H.; Xie, H. Impact of changes in labor resources and transfers of land use rights on agricultural non-point source pollution in Jiangsu Province, China. J. Environ. Manag. 2018, 207, 134-140. [CrossRef] [PubMed]

33. Vasco, C.; Torres, B.; Jácome, E.; Torres, A.; Eche, D. Use of chemical fertilizers and pesticides in frontier areas: A case study in the Northern Ecuadorian Amazon. Land Use Policy 2021, 107, 105490. [CrossRef]

34. Liu, Y.; Feng, C. What drives the fluctuations of "green" productivity in China's agricultural sector? A weighted Russell directional distance approach. Resour. Conserv. Recycl. 2019, 147, 201-213. [CrossRef]

35. Islam, S.F.-U.; Sander, B.O.; Quilty, J.R.; de Neergaard, A.; van Groenigen, J.W.; Jensen, L.S. Mitigation of greenhouse gas emissions and reduced irrigation water use in rice production through water-saving irrigation scheduling, reduced tillage and fertiliser application strategies. Sci. Total Environ. 2020, 739, 140215. [CrossRef]

36. Sun, P.; Liu, L.; Qayyum, M. Energy efficiency comparison amongst service industry in Chinese provinces from the perspective of heterogeneous resource endowment: Analysis using undesirable super efficiency SBM-ML model. J. Clean. Prod. 2021, 328, 129535. [CrossRef] 
37. Berk, I.; Kasman, A.; Kılınç, D. Towards a common renewable future: The System-GMM approach to assess the convergence in renewable energy consumption of EU countries. Energy Econ. 2020, 87, 103922. [CrossRef]

38. Zhang, J.; Mishra, A.K.; Zhu, P.; Li, X. Land rental market and agricultural labor productivity in rural China: A mediation analysis. World Dev. 2020, 135, 105089. [CrossRef]

39. Chen, S.; Shi, A.; Wang, X. Carbon emission curbing effects and influencing mechanisms of China's Emission Trading Scheme: The mediating roles of technique effect, composition effect and allocation effect. J. Clean. Prod. 2020, 264, 121700. [CrossRef]

40. Pan, D.; He, M.; Kong, F. Risk attitude, risk perception, and farmers' pesticide application behavior in China: A moderation and mediation model. J. Clean. Prod. 2020, 276, 124241. [CrossRef]

41. Wang, X.; Yamauchi, F.; Huang, J.; Rozelle, S. What constrains mechanization in Chinese agriculture? Role of farm size and fragmentation. China Econ. Rev. 2020, 62, 101221. [CrossRef]

42. Nunfam, V.F.; Afrifa-Yamoah, E. Heat exposure effect on Ghanaian mining workers: A mediated-moderation approach. Sci. Total Environ. 2021, 788, 147843. [CrossRef] 